\title{
PENINGKATAN HASIL BELAJAR SOSIOLOGI PADA POKOK BAHASAN NILAI DAN NORMA MELALUI PEMBELAJARAN INQUIRY SISWA KELAS X SMA NEGERI 16 MAKASSAR
}

\author{
AKHIRUDDIN \\ akhiruddin114@gmail.com \\ DOSEN FKIP UNIVERSITAS MEGAREZKY
}

\begin{abstract}
Abstrak
Penelitian ini adalah Penelitian Tindakan Kelas (Classroom Action Research) yang bertujuan untuk meningkatkan hasil belajar sosiologi pada siswa kelas X SMA Negeri 16 Makassar melalui pembelajaran Inquiry pada pokok bahasan nilai dan norma. Subjek penelitian ini adalah siswa kelas X SMA Negeri Makassar. Penelitian ini dilaksanakan dalam 2 (dua) siklus. Pada pelaksanaan pembelajaran inquiry merupakan suatu tindakan yang diberikan kepada siswa untuk mengetahui peningkatan dan kemampuan siswa disertai dengan hasil belajar sosiologi. Data yang terkumpul dianalisis secara kuantitatif dan kualitatif.

Setelah dilakukan pembelajaran dengan penerapan inquiry selama dua siklus pembelajaran diperoleh hasil sebagai berikut: (1) kemampuan siswa untuk menyampaikan pendapat dalam menyelesaikan nilai dan norma dari $24,4 \%$ untuk siklus pertama meningkat menjadi $75 \%$ pada siklus kedua. (2) hasil belajar sosiologi siswa pada siklus pertama berada pada ketegori sedang dengan skor rata-rata 65,43 dari skor tertinggi 85 dan skor terendah 55 dari skor maksimun yaitu 100. Hasil belajar sosiologi siswa pada siklus ke dua berada pada kategori tinggi dengan rata-rata 77,10 dari skor tertinggi 100 dan skor terendah 65 dari skor maksimun yaitu 100 .

Dari hasil analisis dapat disimpulkan bahwa peningkatan aktivitas siswa dalam mengemukakan pendapat penyelesaian nilai dan norma meningkat begitupun juga dengan hasil belajar siswa kelas X SMA negeri 16 Makassar.
\end{abstract}

Kata Kunci : Hasil Belajar Sosiologi, Nilai dan Norma, Inquiry

\section{A. PENDAHULUAN}

\section{Latar Belakang}

Sosiologi pendidikan pada dasarnya adalah untuk mempercepat dan meningkatkan pencapaian tujuan pendidikan secara keseluruhan, sosiologi pendidikan tidak akan keluar dari upaya-upaya agar pencapaian tujuan dan fungsi 
pendidikan tercapai menurut pendidikan itu sendiri. Secara universal tujuan dan fungsi pendidikan itu adalah memanusiakan manusia. Itulah sebabnya sistem pendidikan nasional menurut UUSPN No. 20 tahun 2003 pasal 3 adalah untuk mengembangkan kemampuan serta meningkatkan mutu kehidupan dan martabat manusia Indonesia dalam rangka upaya mewujudkan tujuan nasional; (1) mengembangkan kemampuan manusia Indonesia, (2) meningkatkan mutu kehidupan manusia Indonesia, (3) meningkatkan martabat manusia Indonesia, dan (4) mewujudkan tujuan nasional melalui manusia-manusia Indonesia. Oleh karena itu, pendidikan diselenggarakan untuk setiap manusia Indonesia tersebut memiliki kemampuan mengembangkan diri, meningkatkan mutu kehidupan, meningkatkan martabat dalam rangka mencapai tujuan nasional.

Di dalam dunia pendidikan, disadari bahwa sekolah masih perlu meningkatkan kedisiplinannya. Masih banyak ditemukan sekolah-sekolah yang belum berada pada tingkat disiplin yang baik, sehingga hal tersebut akan mempengaruhi hasil belajar atau prestasi siswa yang kurang baik. Disiplin menjadi sarana pendidikan karena dalam mendidik kedisiplinan merupakan peran yang mempengaruhi, mendorong, mengendalikan, mengubah, membina dan membentuk perilaku-perilaku tertentu sesuai dengan nilai-nilai yang ditanamkan, diajarkan, dan diteladankan. Oleh karena itu, sekolah perlu menempatkan kedisiplinan ke dalam prioritas program pendidikan. Dengan demikian, para siswa akan terbawah arus disiplin sekolah yang baik akan melahirkan siswa berprestasi.

Cara yang tepat untuk meningkatkan hasil belajar siswa adalah pengajar harus menciptakan suasana yang terdiri atas berbagai komponen dan tersedianya berbagai metode, salah satu metode yang penulis akan diteliti adalah pembelajaran Inquiry, agar siswa dengan mudahnya mengingat kembali pelajaran yang sudah diajarkan dan tidak jenuh dalam proses belajar mengajar.

Kondisi yang ditemukan banyak siswa sekarang minat belajar sangat rendah. Tentunya banyak alasan dapat dikemukakan sebagai latar belakang. Salah satu gambaran yang dapat dipergunakan sebagai pembanding dalam kenyataan mereka malas belajar dikarenakan guru yang tidak menarik dan tidak antusias dalam mengajar serta tidak menguasai metode pembelajaran. 
Kondisi tidak ideal sebagaimana dikemukakan diatas harus segara diakhiri. Ketidakberdayaan guru untuk menciptakan daya tarik bagi siswa harus segera diakhiri. Kebermaknaan arti seorang guru bagi siswa harus secara utuh dibina. Salah satu cara untuk itu adalah dengan cara guru harus menggunakan metode pembelajaran yang baik dalam proses belajar mengajar.

Kondisi seperti di atas dialami oleh siswa kelas X SMA Negeri 16 Makassar. Berdasarkan hasil wawancara dengan guru bidang studi sosiologi pada sekolah tersebut diperoleh informasi bahwa hasil belajar sosiologi siswa di kelas tersebut tergolong rendah dan ketidak tercapaiannya standar nilai yaitu Kriteria Ketuntasan Minimal (KKM). Hal ini disebabkan karena siswa kurang mampu mengaitkan antara materi yang diajarkan dengan situasi dunia nyata siswa atau dalam kehidupan sehari-hari. Selain itu, juga dikarenakan penyajian materi sosiologi yang masih monoton dan membosankan sehingga siswa kurang tertarik belajar sosiologi.

Oleh karena itu, pendekatan pembelajaran inquiry merupakan strategi yang tepat untuk diterapkan dalam mengatasi masalah rendahnya hasil belajar sosiologi siswa dalam proses belajar sosiologi. Proses pembelajaran berlangsung alamiah dalam bentuk kegiatan siswa bekerja dan mengalami bukan transfer pengetahuan dari guru ke siswa.

\section{Rumusan Masalah}

Berdasarkan uraian latar belakang di atas, tulisan ini hendak menjawab permasalahan yang berkaitan dengan Apakah Penerapan Pembelajaran Inquiry dapat Meningkatkan Hasil Belajar Sosiologi pada Pokok Bahasan Nilai dan Norma Siswa Kelas X SMA Negeri 16 Makassar?

\section{Metode Penelitian}

Penelitian ini adalah Penelitian Tindakan Kelas (Classroom Action Research). Subjek penelitian adalah siswa kelas X SMA Negeri Makassar. Penelitian ini dilaksanakan dalam 2 (dua) siklus. Pada pelaksanaan pembelajaran inquiry merupakan suatu tindakan yang diberikan kepada siswa untuk mengetahui peningkatan dan kemampuan siswa disertai dengan hasil belajar sosiologi. Data yang terkumpul dianalisis secara kuantitatif dan kualitatif. 


\section{B. TINJAUAN PUSTAKA}

\section{Pembelajaran Sosiologi}

Sosiologi adalah bagian dari ilmu-ilmu sosial (social science) yang bersamasama menghadapi masyarakat sebagai objeknya. Seperti yang pernah dikemukakan oleh Aguste Comte (Abdulsyani, 2007: 2) bahwa sosiologi adalah filsafat tentang manusia dan filsafat pergaulan hidup. Konsep yang yang dikemukakan oleh Comte tersebut mencerminkan pengertian bahwa sosiologi itu merupakan pengetahuan yang menyoroti secara tajam mengenai hubungan manusia, golongan, asal, ras, dan kemajuannya, serta bentuk dan kewajibannya.

Sosiologi yang diajarkan di jenjang persekolahan, yaitu Sekolah Menengah Pertama (SMP dengan kata lain IPS Terpadu) dan Sekolah Menengah Atas (SMA) disebut sosiologi sekolah. Sering juga dikatakan bahwa sosiologi sekolah adalah unsur-unsur atau bagian-bagian dari sosiologi yang dipilih berdasarkan atau berorientasi pada kepentingan pendidikan dan perkembangan IPTEK. Sosiologi yang dipilih adalah sosiologi yang dapat menata nalar, membentuk kepribadian, menanamkan nilai-nilai, memecahkan masalah, dan melakukan tugas tertentu.Dalam sosiologi, tujuan umum diberikannya sosiologi pada jenjang pendidikan dasar dan menengah meliputi dua hal, yaitu:

a. Mempersiapkan siswa agar mampu menghadapi perubahan keadaan di dalam kehidupan dan dunia yang selalu berkembang, melalui latihan bertindak atas dasar pemikiran secara logis, rasional, kritis, cermat, jujur, efektif dan efisien.

b. Mempersiapkan siswa agar dapat menggunakan pembelajaran sosiologi dan pola pikir sosiologi dalam kehidupan sehari-hari, dan dalam mempelajari berbagai ilmu pengetahuan.

Adapun tujuan khusus pembelajaran sosiologi di SMA sederajat adalah agar :

a. Siswa memiliki kemampuan yang dapat dialihgunakan melalui kegiatan sosiologi.

b. Siswa memiliki pengetahuan sebagai bekal untuk melanjutkan pendidikan menengah atas.

c. Siswa memiliki keterampilan sosiologi sebagai peningkatan dan perluasan dari sosiologi sekolah dasar untuk dapat digunakan dalam kehidupan sehari-hari. 
d. Siswa memiliki pandangan yang cukup luas dan memiliki sifat logis, kritis, cermat dan disiplin serta menghargai kegunaan sosiologi.

Bahwa pembelajaran sosiologi berperan sebagai wahana pengembangan kemampuan siswa dalam mengaplikasikan pemahamannya terhadap fenomena kehidupan sehari-hari. Sebagai wahana pengembangan kemampuan siswa, materi pelajaran mencakup konsep-konsep dasar, pendekatan, metode, dan teknik analisis dalam pengkajian berbagai fenomena dan permasalahan yang ditemui dalam kehidupan nyata hidup bermasyarakat. Materi tersebut sekaligus menjadi pengantar bagi siswa-siswa yang berminat mendalami sosiologi lebih lanjut.

\section{Hasil Belajar}

Hasil belajar adalah kemampuan-kemampuan yang dimiliki siswa setelah ia menerima pengalaman belajarnya. Kingsley (Sudjana, 1989: 22) membagi tiga macam hasil belajar, yaitu : (a) keterampilan dan kebiasaan; (b) pengetahuan dan pengertian; (c) sikap dan cita-cita yang masing-masing golongan dapat diisi dengan bahan yang ada pada kurikulum sekolah.

Sardiman (2001: 87), secara garis besar faktor-faktor yang mempengaruhi hasil belajar dapat dibedakan menjadi dua jenis yaitu sebagai berikut:

a. Faktor-faktor yang bersumber dari dalam diri manusia. Faktor ini dapat diklasifikasikan menjadi dua yakni faktor biologis dan faktor psikologis. Faktor biologis antara lain usia, kematangan dan kesehatan, sedangkan faktor psikologis adalah kelelahan, suasana hati, motivasi, minat dan kebiasaan belajar.

b. Faktor yang bersumber dari luar manusia. Faktor ini diklasifikasikan menjadi dua yakni faktor manusia dan factor non manusia seperti alam, benda, hewan, dan lingkungan fisik. Beberapa ciri untuk melihat hasil belajar yang diperoleh siswa setelah melakukan proses belajar adalah sebagai berikut: (1) Siswa dapat mengingat fakta, prinsip, konsep yang telah dipelajarinyadalam waktu yang cukup lama. (2) Siswa dapat memberikan contoh dari konsep dan prinsip yang telah dipelajarinya. (3) Siswa dapat mengaplikasikan atau menggunakan konsep dan prinsip yang telah dipelajarinya. (4) Siswa mempunyai dorongan yang kuat untuk mempelajari bahan pelajaran lebih lanjut. (5) Siswa terampil mengadakan hubungan sosial seperti kerja sama dengan siswa lain, berkomunikasi dengan 
orang lain, dan lain-lain. (6) Siswa memperoleh kepercayaan diri bahwa ia mempunyai kemampuan dan kesanggupan melakukan tugas belajar. (7) Siswa menguasai bahan yang telah dipelajari minimal $65 \%$ dari yang seharusnya dicapai.

\section{Nilai Dan Norma}

Manusia adalah makhluk sosial yang selalu berinteraksi dengan individu lain. Untuk menjaga kelangsungan hidup bermasyarakat diperlukan aturan-aturan yang akan terwujud dalam norma dan nilai. Setiap masyarakat memiliki seperangkat nilai dan norma yang berbeda sesuai dengan karakteristik masyarakat itu sendiri.

a. Nilai sosial.

Nilai sosial merupakan landasan bagi masyarakat untuk merumuskan apa yang benar dan penting, memiliki ciri-ciri tersendiri, dan berperan penting untuk mendorong dan mengarahkan individu agar berbuat sesuai norma yang berlaku. Nilai sosial mengacu pada pertimbangan terhadap suatu tindakan benda, cara untuk mengambil keputusan apakah sesuatu yang bernilai itu memiliki kebenaran, keindahan dan nilai ketuhanan.

b. Norma sosial.

Istilah "Peraturan" atau "Tata tertib" sering kita dengar bukan. Bahkan mungkin di antara kita pernah melanggarnya. Istilah itulah yang disebut dengan norma sosial. kita pahami tentang materi norma sosial. Di dalam kehidupan masyarakat, norma berisi tata tertib, aturan, petunjuk standar mengenai perilaku yang pantas atau wajar. Pelanggaran terhadap norma akan mendatangkan sanksi, dari bentuk cibiran atau cemoohan sampai ke sanksi fisik dan psikis berupa pengasingan atau diusir dari tempat tinggalnya yang bertujuan agar pelakunya jera. Oleh karena itu, Norma adalah petunjuk atau patokan untuk melangsungkan hubungan sosial dalam masyarakat yang berisi perintah, larangan dan anjuran agar seseorang dapat bertingkah laku yang pantas, untuk menciptakan ketertiban, keteraturan, kedamaian dalam bermasyarakat

c. Peran Nilai dan Norma dalam Masyarakat

Nilai dan norma dalam masyarakat sangat berperan dalam memberikan stabilitas kehidupan. Coba bayangkan jika suatu daerah tidak terdapat suatu nilai dan 
norma sosial yang berlaku, pastilah daerah tersebut akan mengalami kekacauan dan pola kehidupannya akan mengalami penyimpangan. Misalnya, di daerah Papua, dimana daerah tersebut belum mampu melembagakan suatu norma, akibatnya masyarakat disana tidak tahu bagaimana cara berpakaian sopan didepan umum, bagaimana cara mereka mengikat tali perkawinan yang suci sesuai agama dan bagaimana mereka bersosialisasi dengan damai.

\section{Metode Inquiry}

Inquiry (menemukan) merupakan bagian inti dari kegiatan pembelajaran yang berbasis CTL. Pengetahuan dan keterampilan yang diperoleh siswa diharapkan bukan hasil mengingat seperangkat fakta-fakta, tetapi hasil dari penemuan sendiri. Guru harus selalu merancang kegiatan yang merujuk pada kegiatan menemukan, apapun materi yang diajarkan. Siswa harus mampu menemukan pengetahuan sendiri bukan berdasarkan buku.Adapun keunggulan dari teknik inquiry ini menurut (Roestiyah 2001:76-77) adalah: (a) Dapat membentuk mengembangkan "selconsept" pada diri siswa, sehingga siswa dapat mengerti tentang konsep dasar dan ide-ide lebih baik. (b) Membantu dalam menggunakan ingatan dan transfer pada situasi proses belajar yang baru. (c) Mendorong siswa untuk berpikir dan bekerja atas inisiatifnya sendiri, bersikap objektif, jujur dan terbuka sehingga memberikan hasil yang maksimal. (d) Mendorong siswa untuk berpikir intuitif dan merumuskan hipotesisnya sendiri. (e) Memberi keputusan yang bersifat intrinsik (f) Situasi proses belajar lebih merangsang. (g) Dapat mengembangkan bakat atau kecakapan individu. (h) Memberi kebebasan siswa untuk belajar sendiri. (i) Siswa dapat menghindari siswa dari cara-cara belajar yang tradisional. (j) Dapat memberikan waktu pada siswa secukupnya sehingga mereka dapat mengasimilasi dan mengakomodasi informasi.

Inquiry pendekatan peranan siswa dilibatkan dalam proses pemecahan masalah, yang cara-caranya serupa dengan cara-cara yang biasa diikuti oleh para "ilmuwan" suatu undangan memberikan suatu masalah kepada siswa, dan dengan pertanyaan yang telah direncanakan dengan teliti, mengundang siswa untuk melakukan kegiatan seperti: merancang eksperimen, merumuskan hipotesis, menetapkan pengawasan dan seterusnya. 


\section{HASIL PENELITIAN}

Hasil penelitian yang memperlihatkan peningkatan prestasi belajar siswa dengan menggunakan pembelajaran Inquiry pada pokok bahasan nilai dan norma pada siswa kelas X SMA Negeri 16 Makassar, aktivitas serta pola-pola interaksi yang terjadi antara guru dan siswa pada saat kegiatan pembelajaran berlangsung. Adapun Deskripsi Hasil Penelitian terdiri dari siklus I dan siklus II sebagai berikut;

\section{SIKLUS I}

\section{Tahap Perencanaan}

Pada tahap ini peneliti akan berdiskusi dengan guru mata pelajaran untuk membahas permasalahan yang akan dipecahkan dalam penelitian ini setelah itu menelaah kurikulum berdasarkan kurikulum 13, adapun standar kompetensi yang akan dicapai melalui kegiatan pembelajaran adalah menganalisis kelompok sosial dalam nilai dan norma. Selanjutnya, setelah menetapkan metode ajar peneliti membuat Rencana Kegiatan Pembelajaran (RPP) dengan menggunakan pembelajaran pendekatan Inquiry, disamping itu peneliti juga menyiapkan bahan-bahan penunjang untuk kelancaran penelitian antara lain, pedoman observasi, membuat silabus, kriteria ketuntasan minimimal (KKM) dan menyusun alat evaluasi serta tes hasil belajar siklus pertama.

\section{Tahap Pelaksanaan Tindakan}

Pertemuan I; Pada pertemuan pertama peneliti akan membuka pelajaran dengan memberikan penjelasan mengenai maksud dan tujuan diadakannya penelitian di SMA Negeri 16 makassar, disamping itu peneliti akan memberikan rangsangan kepada siswa dengan mengulas kembali materi terdahulu yang berhubungan dengan materi nilai dan norma disamping peneliti akan memberikan himbauan dan motivasi untuk membaca buku-buku dan media yang lain yang berkaitan dengan materi yang akan di bahas. Selanjutnya, peneliti memberikan tugas individu yang berhubugan dengan materi nilai dan norma yang ada sekitar lingkungan siswa setelah itu setiap siswa akan membacakan tugasnya di depan kelas.

Pertemuan II; Peneliti akan membagi siswa menjadi enam kelompok yang terdiri atas lima sampai enam anggota kelompok yang dikelompokkan secara heterogen, peneliti kemudian membagikan topik yang akan didiskusikan tiap kelompok diikuti dengan memberikan rangsangan berfikir bagaimana cara berpartisipasi dalam penelitian 
ini, peneliti akan memberikan tahap penyelesaian tugas kelompok sampai pada tatacara berdiskusi. Dari cara membuka diskusi, sampai tahap pengambilan kesimpulan diskusi.

Pertemuan III; Pada pertemuan ketiga ini setiap kelompok akan mempersentasikan hasil diskusi kelompoknya. Kelompok dari urutan pertama sampai keenam memilih anggota kelompok yang akan jadi moderator, pembaca materi, setiap kelompok bergiliran naik didepan kelas untuk mempertanggung jawabkan hasil diskusi kelompoknya dan kelompok lain memberi pertanyaan, masukan ataupun tanggapan dan peneliti mengatur kesempatan pada siswa yang ingin berpendapat agar diskusi tetap berjalan alot dan tidak keluar dari tema diskusi tahap akhir dari diskusi ini adalah setiap kelompok akan memberikan kesimpulan hasil diskusi kelompok dibantu oleh peneliti dengan memberikan pemantapan, selanjutnya peneliti memberikan tugas pekerjaan rumah disertai dengan menutup pelajaran.

\section{Tahap observasi dan evaluasi}

Berdasarkan hasil observasi diperoleh gambaran bahwa motivasi, minat dan perhatian siswa selama mengikuti kegiatan pembelajaran sosiologi yaitu:

a) Rata-rata persentase siswa yang hadir dalam proses pembelajaran mencakup 83,3\%.

b) Rata-rata hasil persentasi siswa yang melakukan kegiatan diluar proses belajar mengajar seperti menganggu temannya mencakup 34,4\%.

c) Rata-rata hasil persentase siswa yang aktif mengemukakan pendapatnya saat diskusi mencakup $35,5 \%$.

d) Rata-rata persentasi siswa yang menyetor pekerjaan rumah mencakup $68,8 \%$.

e) Rata-rata persentase siswa yang masih perlu bimbingan mengenai materi pelajaran mencakup $20 \%$.

Berdasarkan hasil evaluasi yaitu berupa tes hasil belajar siswa diperoleh tabel statistik deskriptif sebagai berikut.

Tabel. Statistik Hasil Belajar Sosiologi untuk siklus I

\begin{tabular}{|c|c|}
\hline Statistik & Nilai Statistik \\
\hline Subjek & 30 \\
\hline Skor ideal & 100 \\
\hline Skor tertinggi & 85 \\
\hline Skor terendah & 55 \\
\hline Rentang skor & 55 \\
\hline Rata-rata & 65,43 \\
\hline
\end{tabular}


Apabila skor hasil belajar siswa dikelompokkan kedalam lima kategori, maka diperoleh distribusi frekuensi yang ditunjukkan pada tabel dibawah ini.

\begin{tabular}{|c|c|c|c|}
\hline Skor & Kategori & Frekuensi & Persentase \\
\hline $0-34$ & Sangat rendah & - & $0 \%$ \\
\hline $35-54$ & Rendah & - & $0 \%$ \\
\hline $55-64$ & Sedang & 17 & $56,67 \%$ \\
\hline $65-84$ & Tinggi & 12 & $40 \%$ \\
\hline $85-100 \quad$ Sangat tinggi & 1 & $3,3 \%$ \\
\hline \multicolumn{2}{|c|}{ Jumlah } & 30 & $100 \%$ \\
\hline
\end{tabular}

Berdasarkan tabel dan dideskripsikan bahwa hasil belajar sosiologi siswa pada Kelas X SMA Negeri 16 Makassar, setelah dilakukan tindakan pada siklus I berada dalam kategori sedang dengan rata-rata 56,67\% dengan perolehan skor untuk siklus I adalah 85 untuk skor tertinggi dan 55 untuk skor terendah dari skor ideal yang mungkin dicapai yaitu $100 \%$.

Sedangkan pada tabel di atas menunjukkan bahwa dari 30 siswa yang mengikuti tes hasil belajar terdapat $0 \%$ siswa masuk dalam kategori sangat rendah, $0 \%$ siswa masuk dalam kategori rendah, $17 \%$ siswa masuk dalam kategori sedang, $12 \%$ siswa masuk dalam kategori tinggi, sedangkan siswa yang masuk dalam kategori sangat tinggi adalah $1 \%$ dari skor rata-rata penguasaan sosiologi siswa kelas X SMA Negeri 16 Makassar 65,43 dari skor ideal 100.

Gambaran ketuntasan belajar siswa Kelas X SMA Negeri 16 Makassar yang diperoleh berdasarkan skor hasil belajar adalah sebagai berikut:

Tabel. Deskripsi Ketuntasan Belajar Siswa Kelas X SMA Negeri 16 Makassar.

\begin{tabular}{|c|c|c|c|}
\hline Skor & Kategori & Frekuensi & Persentase \\
\hline $0-64$ & Tidak tuntas & 17 & $56,67 \%$ \\
\hline $65-100$ & Tuntas & 13 & $43,33 \%$ \\
\hline \multicolumn{2}{|c|}{ Jumlah } & 30 & $100 \%$ \\
\hline
\end{tabular}

Dari tabel 4.3, menunjukkan persentase ketuntasan belajar siswa Kelas X SMA Negeri 16 Makassar sebesar 43,33\% atau 13 dari 30 siswa termasuk dalam kategori tuntas dan 56,67\% atau 17 dari 30 siswa termasuk dalam kategori tidak tuntas.

\section{Tahap refleksi I}

Pada pertemuan pertama siklus I ini merupakan awal dengan menggunakan pendekatan dari model pembelajaran baru yang berbeda dengan apa yang digunakan 
pada pertemuan-pertemuan sebelumnya. Sehingga pertemuan ini merupakan tahap penyesuaian terhadap pendekatan dan model yang diterapkan.

\section{Keputusan}

Karena hasil akhir dari siklus I belum menunjukkan hasil yang maksimal, maka peneliti akan merencanakan dan menguji kembali penerapan metode ini dalam siklus kedua.

\section{SIKLUS II}

\section{Tahap Perencanaan}

Pada tahap ini relatif sama pada tahap perencanaan siklus pertama, yaitu melaksanakan diskusi awal dengan guru mata pelajaran sosiologi dalam penelitian ini setelah itu menelaah kurikulum berdasarkan kurikulum 13, adapun standar kompetensi yang akan dicapai melalui kegiatan pembelajaran adalah menganalisis kelompok sosial dalam nilai dan norma. Selanjutnya, setelah menetapkan metode ajar peneliti membuat Rencana Kegiatan Pembelajaran (RPP) dengan menggunakan pembelajaran pendekatan Inquiry, disamping itu peneliti juga menyiapkan bahan-bahan penunjang untuk kelancaran penelitian antara lain, pedoman observasi, membuat silabus, Kriteria Ketuntasan Minimimal (KKM) dan menyusun alat evaluasi serta tes hasil belajar untuk siklus II.

\section{Tahap Pelaksanaan Tindakan}

Siklus kedua akan dilaksanakan selama empat kali pertemuan dengan tiga kali pertemuan dan satu kali pertemuan untuk melaksanakan evaluasi akhir, dimana setiap pertemuan terdiri atas beberapa tahap, yaitu:

I. Tahap Awal:
a) Membuka pelajaran
b) Pemberian motivasi dan review

II. Tahap Inti:
a) Membantu siswa menyiapkan bahan atau media yang diperlukan dalam penelitian ilmiah
b) Peneliti memberikan rangsangan berfikir
c) Peneliti mempersilahkan siswa untuk melanjutkan diskusi kemarin 
d) Memberikesempatan pada siswa untuk berpendapat dan berdiskusi sesuai dengan tema peneliti

e) Peneliti memberi pertanyaan kepada siswa

III. Tahap Akhir

a) Peneliti menyimpulkan hasil diskusi dan memberikan pemantapan

b) Peneliti memberikan himbauan dan motivasi kepada siswa untuk membaca bukubuku yang berkaitan dengan materi yang akan dibahas.

c) Peneliti menutup pelajaran

\section{Tahap Observasi dan Evaluasi}

Pada tahap ini dilaksanakan proses observasi terhadap pelaksanaan tindakan dengan menggunakan lembar observasi yang telah dibuat serta melaksanakan evaluasi berupa tes hasil belajar siklus II setelah 3 kali pertemuan. Tes hasil belajar siswa yang diberikan berbentuk uraian sebanyak 5 item. Berdasarkan hasil observasi diperoleh gambaran bahwa aktivitas dan kehadiran siswa selama mengikuti kegiatan pembelajaran sosiologi semakin meningkat, yaitu:

a) Rata-rata hasil persentase siswa yang hadir dalam proses pembelajaran mencakup $97,7 \%$

b) Rata-rata hasil persentasi siswa yang melakukan kegiatan diluar proses belajar mengajar seperti menganggu temannya mencakup 16,6\%

c) Rata-rata hasil persentase siswa yang aktiv mengemukakan pendapatnya saat diskusi mencakup $75,5 \%$

d) Rata-rata persentasi siswa yang menyetor pekerjaan rumah mencakup $88,8 \%$

e) Rata-rata persentase siswa yang masih perlu bimbingan mengenai materi pelajaran mencakup $11,1 \%$

Berdasarkan hasil evaluasi yaitu berupa tes hasil belajar siswa diperoleh tabel statistik deskriptif sebagai berikut dimana untuk uraian lengkapnya dapat dilihat pada lampiran. 
Tabel. Statistik Hasil Belajar Persentase Skor Hasil Belajar sosiologi Siklus II

\begin{tabular}{|c|c|}
\hline Statistik & Nilai Statistik \\
\hline Subjek & 30 \\
\hline Skor ideal & 100 \\
\hline Skor tertinggi & 100 \\
\hline Skor terendah & 65 \\
\hline Rentang skor & 60 \\
\hline Rata-rata & 77,10 \\
\hline
\end{tabular}

Apabila skor hasil belajar siswa dikelompokkan kedalam lima kategori, maka diperoleh distribusi frekuensi yang ditunjukkan pada tabel berikut.

Tabel. Distribusi Frekuensi dan Persentase Skor Hasil Belajar Belajar sosiologi

\begin{tabular}{|c|c|c|c|}
\hline Skor & Kategori & Frekuensi & Persentase \\
\hline $0-34$ & Sangat rendah & - & $0 \%$ \\
\hline $35-54$ & Rendah & - & $0 \%$ \\
\hline $55-64$ & Sedang & - & $0 \%$ \\
\hline $65-84$ & Tinggi & 24 & $80 \%$ \\
\hline $85-100$ & Sangat tinggi & 6 & $20 \%$ \\
\hline \multicolumn{2}{|c|}{ Jumlah } & 30 & $100 \%$ \\
\hline
\end{tabular}

Berdasarkan tabel pertama di atas, adapun deskripsi bahwa hasil belajar sosiologi siswa pada Kelas X SMA Negeri 16 Makassar setelah dilakukan tindakan pada siklus II berada dalam kategori sedang dengan rata-rata 77,10 Perolehan skor untuk siklus II adalah 100 untuk skor tertinggi dan 55 untuk skor terendah dari skor ideal yang mungkin dicapai yaitu $100 \%$.

Sedangkan pada tabel di atas yang kedua menunjukkan bahwa dari 30 siswa yang mengikuti tes hasil belajar terdapat $0 \%$ siswa masuk dalam kategori sangat rendah, $0 \%$ siswa masuk dalam kategori rendah, $0 \%$ siswa masuk dalam kategori sedang, $80 \%$ siswa masuk dalam kategori tinggi, sedangkan siswa yang masuk dalam kategori sangat tinggi adalah $20 \%$ dari Skor rata-rata pengguasaan sosiologi siswa kelas X SMA Negeri 16 Makassar 77,10 dari skor ideal 100. Gambaran ketuntasan belajar siswa kelas X SMA Negeri 16 Makassar yang diperoleh berdasarkan skor hasil belajar adalah sebagai berikut: 
Tabel. Deskripsi Ketuntasan Belajar Siswa X SMA Negeri 16 Makassar

\begin{tabular}{|c|c|c|c|}
\hline Skor & Kategori & Frekuensi & Persentase \\
\hline $0-64$ & Tidak tuntas & - & $0 \%$ \\
\hline $65-100$ & Tuntas & 30 & $100 \%$ \\
\hline \multicolumn{2}{|c|}{ Jumlah } & 30 & $100 \%$ \\
\hline
\end{tabular}

Dari tabel menunjukkan persentase ketuntasan belajar siswa Kelas X SMA Negeri 16 Makassar sebesar 100\% atau 30 dari 30 siswa.

\section{Tahap Refleksi Siklus II}

Sesuai dengan apa yang telah diamati peneliti, penggunaan pembelajaran inquiry dalam pelajaran sosiologi kelas X pada siklus kedua ini, maka dapat pula diambil suatu kesimpulan bahwa metode tersebut telah memberikan hasil yang maksimal. ini terbukti dengan bersemangatnya siswa dalam proses kegiatan belajar mengajar dikelas sehingga suasana kelas menjadi hidup. Dari pengamatan juga dapat diketahui secara langsung bahwa dengan metode tersebut suasana kelas menjadi hidup. Hal ini juga dibuktikan dengan banyaknya siswa yang ikut aktif dalam mengajukan pendapat dan memecahkan suatu permasalahan, siswa juga seringkali menggunakan buku rujukan yang ada kaitannya dengan permasalahan dan juga disertai dengan alasan-alasan yang rasional. Hal lain juga terlihat bahwa secara umum ada peningkatan yang signifikan hasil belajar siswa dari siklus pertama ke siklus ke dua.

\section{Keputusan}

Dari dua siklus yang telah dilaksanakan dengan menggunakan pendekatan inquiry diperoleh hasil sebagai berikut:

a) Setiap siswa sudah mampu memahami makna daripada sosiologi sesungguhnya,yang dikaitkan dengan kehidupan nyata.

b) Dapat meningkatkan motivasi belajar sebagian siswa hal ini terlihat pada hasil observasi yang dilakukan oleh peneliti.

c) Walaupaun terjadi peningkatan hasil belajar siklus I ke siklus II dengan menggunakan pendekatan inquiry, peneliti berhenti sampai disini dan berharap ada peneliti lain yang ada dapat melanjutkan penelitian tersebut. 


\section{KESIMPULAN DAN SARAN}

\section{Kesimpulan}

a) Penerapan pembelajaran inquiry (menemukan) di kelas X SMA Negeri 16 Makassar, maka semangat belajar siswa semakin bertambah yang dibuktikan dengan banyaknya siswa yang sering berargumen dalam memecahkan suatu permasalahan dengan menggunakan literatur yang telah dibaca serta aktif khususnya mengenai nilai dan norma.

b) Adanya perubahan yang tampak pada diri siswa setelah mempelajari materi nilai dan norma ini terlihat dengan makin bersemangatnya siswa dalam mengerjakan tugas-tugas yang diberikan yaitu pada siklus pertama mencapai 68,8\% meningkat menjadi $88,8 \%$.

c) Ditinjau dari hasil belajar siswa dengan menggunakan pendekatan inquiry pada kelas X SMA Negeri 16 Makassar ini terlihat nilai siswa untuk siklus pertama yaitu pada siklus I berada dalam kategori sedang dengan rata-rata 65,43. Perolehan skor untuk siklus I adalah 85 untuk skor tertinggi dan 55 untuk skor terendah dari skor ideal yang mungkin dicapai yaitu 100\%. Siklus ke II hasil belajar sosiologi dalam kategori tinggi dengan rata-rata 77,10 dengan Perolehan skor untuk siklus II adalah 100 untuk skor tertinggi dan 65 untuk skor terendah dari skor ideal yang mungkin dicapai yaitu $100 \%$.

\section{Saran}

a) Perlu adanya kerjasama antara personalia yang ada dilingkungan sekolah tentang pentingnya interaksi antara guru dengan murid sebagai upaya pengembangan potensi daya pikir mereka dan upaya untuk melatih siswa dalam memecahkan masalahnya secara mandiri.

b) Siswa sepatutnya belajar dan membaca buku-buku pengetahuan lainnya yang dapat menunjang terhadap pemahamannya tentang ilmu sosiologi, sehingga setiap permasalahan yang diajukan oleh guru dapat dijawab dengan benarserta siswa juga dapat menemukan berbagai permasalahan guna dipecahkan sehingga dapat menumbuhkan kekritisan siswa. 


\section{DAFTAR PUSTAKA}

Abdulsyani. 2007. Sosiologi Skematika, Teori dan Terapan. PT Bumi Aksara. Jakarta

Alwi. 1997. Kamus Besar Berbahasa Indonesia Edisi III. Balai Pustaka. Jakarta

Bagong, Suyanto, J. Dwi Narwoko. 2007. Sosiologi Teks Pengantar dan Terapan. Prenada Media Group. Jakarta

Budiati. 2009. Sosiologi Kontestual untuk SMA \& MA. CV Mediatama. Jakarta

Bahar, Wilis, Ratna. 1981. Teori-Teori Belajar. Erlangga. Jakarta

Gulo. 2002. Strategi Belajar Mengajar. PT Gramedia Widiasarana Indonesia. Jakarta

Hamalik, Oemar. 2001. Proses Belajar Mengajar. PT Rineka Cipta. Jakarta

Roestiyah. 2001. Strategi Belajar Mengajar. PT Rineka Cipta. Jakarta

Sardiman. 2001. Interaksi dan Motivasi Belajar Mengajar. PT Rineka Cipta. Jakarta

Soemardjan, Selo dan Soelaeman, Soemardi. 1974. Setangkai Bunga Sosiologi. Yayasan Badan Penerbit Fakultas Ekonomi Universitas Indonesia. Jakarta

Soekanto, Soerjono. 2010. Sosiologi Suatu Pengantar. Rajawali Pers. Jakarta

Sudjana. 1989. Dasar-Dasar Proses Belajar Mengajar. Sinar Bandung. Bandung

Slameto. 2003. Belajar dan Faktor-Faktor yang Mempengaruhi. PT Rineka Cipta. Jakarta

Tilaar. 1999. Beberapa Agenda Reformasi Pendidikan Nasional dalam Perspektif Abad 21. Tera Indonesia. Magelang

Undang-Undang RI Nomor 20 Tahun 2003 Tentang Sistem Pendidikan Nasional. Departemen Pendidikan Nasional

Weber, Max. 1974. Teory Of Social and Economic Organization. Oxford University Press. New York 